\title{
Growth performance, carcass characteristics and meat quality of growing rabbits housed in cages or open-air park
}

\author{
Victor Pinheiro ${ }^{1,2}$, Divanildo Outor-Monteiro ${ }^{1,2}$, Severiano Silva ${ }^{1,2}$, José Silva ${ }^{3}$ and José \\ Luís Mourão ${ }^{1,2}$ \\ ${ }^{1}$ Centro de Estudos em Ciência Animal e Veterinária (CECAV), ${ }^{2}$ Departement of Animal Science, ${ }^{3}$ Departement of \\ Veterinary Science; Universidade de Trás-os-Montes e Alto Douro (UTAD), Vila Real, Portugal
}

\begin{abstract}
The study was carried out to investigate the effects of two housing systems on the growth performance, carcass traits, and meat quality of growing rabbits during the terminal fattening period. The rabbits were lodged in conventional cages between 35 and 59 days of age (growing period). At this age, they were moved into two different housing systems until they were 87 days of age (fattening period). During the fattening period, 48 rabbits were housed in 12 wire cages $(0.5 \times 0.6 \times 0.35 \mathrm{~m})$ and 48 rabbits were housed in one open-air pasture pen $(20 \times 9 \mathrm{~m})$. At 87 days, 12 rabbits per treatment were slaughtered and the carcass characteristics and meat quality were evaluated. During the fattening period, the rabbits reared in cages had significantly higher live weights ( 3062 vs. $2705 \mathrm{~g}$ ), weight gains (45.9 vs. $\left.34.2 \mathrm{~g} \cdot \mathrm{d}^{-1}\right)$ and feed intakes $\left(163.4 \mathrm{vs} .110 .2 \mathrm{~g} \cdot \mathrm{d}^{-1}\right)$ than those reared in pens. The rabbits in the open-air group had a lower percentage of dissectible fat (1.35 vs. $4.19 \%)$, a higher proportion of hind part (34.9 vs. $33.1 \%)$, and less hind leg muscle (79.3 vs. $81.9 \%)$ than caged rabbits. The $m$. biceps femoris of the rabbits in the open-air group had a higher cooking loss (3.64 vs. $3.02 \%)$, Warner-Bratzler Shear Force (4.26 vs. $\left.3.29 \mathrm{~kg} \cdot \mathrm{cm}^{-2}\right)$, and myoglobin concentration $\left(0.41 \mathrm{vs} .0 .32 \mathrm{mg} \cdot \mathrm{g}^{-1}\right)$ than caged rabbits. The housing system had no effect on the dressing out percentage, viscera proportion, and ultimate $\mathrm{pH}$. Open-air housing system reduces the growth of rabbits and the fat content of carcasses and increases the redness colour of meat.
\end{abstract}

Keywords: rabbit, growth, carcass, meat, housing system

\section{Zusammenfassung}

\section{Mastleistung, Schlachtkörperqualität und Fleischqualität von wachsenden Kaninchen untergebracht in Drahtkäfigen oder Freilandkäfigen}

Die Studie wurde durchgeführt um die Auswirkungen der Haltungssysteme in der Endmastperiode auf die Leistung, Schlachtleistung und Fleischqualität von wachsenden Kaninchen zu untersuchen. Die Kaninchen wurden in konventionellen Käfigen zwischen dem 35 bis 59 Lebenstag (Wachstumperiode) untergebracht, und ab diesem Alter bis zum 87 Lebenstag (Mastperiode) auf zwei verschiedene Haltungssysteme gehalten. In diesem Zeitraum wurden 48 Kaninchen in 12 Drahtkäfigen $(0.5 \times 0.6 \times 0.35 \mathrm{~m}$; 4 Kaninchen pro Käfig) und 48 Kaninchen in einem Freilandkäfig $(20 \times 9 \mathrm{~m})$ untergebracht. Am Tag 87 wurden 12 Kaninchen pro Behandlung geschlachtet und die Schlachtkörperqualität und Fleischqualität 
gemessen. Während der Mastperiode zeigten Kaninchen in Drahtkäfigen ein höheres $(P<0,05)$ Lebendgewicht (3062 vs $2705 \mathrm{~g}$ ) und eine höhere Gewichtszunahme (45,9 vs 34,2 g·t ${ }^{-1}$ ) als die in Freilandkäfige aufgezogene Tiere. Die in Freilandkäfige gehaltene Kaninchen hatten einen geringeren Prozentsatz des sezierten Fettes (1,35 vs 4,19\%), einen höherer Anteil des Hinterleib (34,9 vs 33,1\%) und die Hinterläufe hatten weniger Muskel (79,3 vs 81,9\%). Der M. biceps femoris an der Freilandkäfige gehaltene Kaninchen hatten einen höhere Kochverlust (3,64 vs 3,02\%), eine höhere Warner-Bratzler Scherkraft (4,26 vs 3,29 $\left.\mathrm{kg} \cdot \mathrm{cm}^{-2}\right)$ und eine höhere Myoglobin Konzentration $\left(0,41 \mathrm{vs} 0,32 \mathrm{mg} \cdot \mathrm{g}^{-1}\right)$. Das Haltungssystem hatte keinen Einfluss auf Ausbeute Prozentsatz, Eingeweideanteil und pHu. Freiland Käfighaltung reduziert das Wachstum von Kaninchen und Fettgehalt der Schlachtkörper und erhöht die Rötung des Fleisches.

Schlüsselwörter: Kaninchen, Wachstum, Schlachtkörper, Fleisch, Haltungssystem

\section{Introduction}

In recent years, consumer interest in specialty products derived from free-range or organic production systems has steadily increased in Europe and in other parts of the world. Customers who prefer rabbit specialty products have expectations of higher quality meats derived from these systems and higher standards of animal welfare. To meet these consumer expectations, several studies have examined alternative housing systems for fattening rabbits (Maertens \& Van Oeckel 2001, Pla 2008, Jekkel et al. 2010). Cages with different sizes, different stocking densities and group sizes, pens with litter, open-air pens, and movable cages have been proposed, although in most cases there is little scientific evidence to support these options. Generally, extensive housing systems provide animals with more space and freedom of movement, which permits a broad range of behaviour patterns and better satisfies the natural and social needs of rabbits (Morisse et al. 1999). Consumers, scientists, and the food industry need concrete information on the effects of extensive housing systems on animal welfare as well as on meat quality and animal health. Verga (2000), Marai \& Rashwan (2004) and Pinheiro \& Mourão (2007) have reviewed the main results of the studies in this field.

Rabbit pasture pen housing systems provide more space and a more 'natural' environment than conventional cages. However, when rabbits are kept in pastures, they may come into contact with faeces, which can increase health problems, such as enteric diseases and coccidiosis, and reduce growth performance. In order to determine the feasibility of extensive housing systems, some alternative organic production systems for growing rabbits that involved movable cages were tested in small farms in Italy (Cavani et al. 2000) and France (Lebas 2001). In these studies, the rabbits were placed in movable cages that were provided with water and feed, and the cages were moved in the pastures.

Several studies have reported that housing systems can affect body weight, carcass traits and sometimes meat quality (Mertens \& van Oeckel 2001, Pla 2008) and reproductive behaviour (Marai \& Rashwan 2003). Housing systems with floor pens or colony cages seem to reduce stress and aggressive behaviour in animals (Mertens \& van Oeckel 2000, Lebas 2001) but these systems increase mortality and decrease growth rates, feed intake, feed efficiency, and sometimes meat quality (Dal Bosco et al. 2000, Lambertini et al. 2001, Combes 
et al. 2003, McNitt et al. 2003). However, the studies on extensive housing systems have often been inconclusive due to the numerous variables involved (stocking density, group size, type of pen, and others).

The aim of this study was to examine the effects of housing systems (cages or open-air pens) on the growth performance of rabbits at the end of fattening period when the animals were between 59 and 87 days old. Moreover, the carcass characteristics and meat quality were compared.

\section{Material and methods}

\section{Animals, housing treatments and diets}

The study was carried out at the Experimental Rabbit Facilities of the Animal Production Department at the University of Trás-os-Montes e Alto Douro (UTAD) in Vila Real, Portugal. Hybrid rabbits of both sexes (New Zealand WhitexCalifornian) were housed under controlled conditions from 35 to 87 days of age (d).

The rabbits were divided into two groups and subjected to two housing treatments: a) cage treatment, where rabbits were housed in cages during the growing and fattening periods, and b) open-air treatment where rabbits were housed in cages during the growing period and in a pasture pen during the fattening period. All of the rabbits were fed ad libitum with commercial pellet feed (containing $92.2 \%$ organic matter, $15.9 \%$ crude protein, $25.2 \%$ starch, $3.5 \%$ crude fat, and $16.8 \%$ acid detergent fibre [ADF]) and had free access to water. The animals in the open-air treatment group also had access to the natural pasture available in the pen during the growing period.

The study was divided into two periods: the growing period ( 35 to $59 \mathrm{~d}$ ) and the fattening period ( 59 to $87 \mathrm{~d}$ ). At $35 \mathrm{~d}$ the rabbits were sexed and tattooed for individual identification. In both periods, there were equal proportions of both sexes (half males and half females) housed in the cages or pens. During the growing period, 144 rabbits were lodged in 24 wire cages (cage dimensions: $0.5 \times 0.6 \times 0.35 \mathrm{~m}$ ) with 6 animals/cage. The animals were lodged in a temperaturecontrolled building and were exposed to $12 \mathrm{~h}$ of light daily (8:00 to 20:00). During the fattening period, only 96 rabbits were used because the cages with high morbidity and mortality during the growing period were excluded. Forty-eight rabbits were reared under conditions similar to the growing period, but the number of animals per cage was reduced to 4 (12 cages). The second group of 48 rabbits was kept in one pasture pen $(20 \times 9 \mathrm{~m})$ in a natural environment. The dominant species within the pasture hays in the Northeast region of Portugal are red fescue (Festuca rubra L.), creeping velvetgrass (Holcus mollis L.), common velvetgrass (Holcus lanatus L.), bristle bent (Agrostis setacea Curtis), perennial ryegrass (Lolium perenne L.), and smooth brome (Bromus inermis Leyss). Legumes are present at a low proportion $(\mathrm{w} / \mathrm{w})$ representing approximately $120 \mathrm{~g} / \mathrm{kg}$ of species. The chemical composition of these hays is, on average $(\mathrm{g}$ per kg of hay), 8 crude protein, 70 neutral detergent fibre and 6 ash (Rodrigues et al. 2007).

\section{Measurements}

The individual body weights and feed intakes of the rabbits were recorded at 35 and $59 \mathrm{~d}$, and then measured weekly to determine the daily weight gain and daily feed intake. The 
pasture feed intake during the fattening period was not controlled. In this period, the deaths of rabbits were controlled for, and the mortality rate was determined.

At the end of the fattening period ( $87 \mathrm{~d}$ ), 12 rabbits per treatment were slaughtered, and the carcasses were obtained and dissected in accordance with the norms of the World Rabbit Science Association (WRSA) (Blasco \& Ouhayoun 1996). Carcasses with the head, liver, kidneys, and thoracic viscera (lungs, thymus, oesophagus, and heart) were suspended from the tendon calcaneus for $60 \mathrm{~min}$ in a ventilated area and then cooled at $3^{\circ} \mathrm{C}$ for $24 \mathrm{~h}$. The carcasses were then weighed to obtain the chilled carcass weight. The dressing out percentage (chilled carcass weight/live weight) was calculated. The drip loss percentage (DLP) was determined as the difference between the hot carcass weight and chilled carcass weight, relative to the hot carcass weight. The head, liver, kidneys, and thoracic viscera were removed and weighed to obtain the reference carcass weight. The perirenal and scapular fat (dissectible fat) of the carcass were removed and weighed. Next, the hind part was obtained by the technological division (Blasco \& Ouhayoun 1996) and the bone and meat of the right hind legs were dissected, and the weights were recorded. The femur length and diameter were recorded, and the length of the femur was expressed as a function of the live weight. The head, liver, and reference carcass weights were expressed as a percentage of the chilled carcass weight. The hind part and dissectible fat weights were expressed as a percentage of the reference carcass weight. The meat to bone ratio of the hind leg was calculated as the ratio between the weights of the dissected meat and the bone.

The carcass and meat colours were measured at $24 \mathrm{~h}$ post-mortem in accordance Ouhayoun \& Dalle Zotte (1996) using a Minolta CR-300 Chroma Meter (Minolta Camera, Osaka, Japan) in the CIELAB colour space: lightness $\left(\mathrm{L}^{*}\right)$, redness $\left(\mathrm{a}^{*}\right)$ and yellowness $\left(\mathrm{b}^{*}\right)$. The carcass colour was determined on the surface of the left $m$. biceps femoris. The meat colour was measured on the transversal section of this muscle. The ultimate $\mathrm{pH}(\mathrm{pHu})$ was measured at slaughter and again $24 \mathrm{~h}$ post-mortem $\left(\mathrm{pHu}_{24 \mathrm{~h}}\right)$ in the right $m$. biceps femoris by penetrating the muscle with a 5-mm glass pH electrode ( $\mathrm{pH}$ 91, WTW, Weilheim, Germany).

The cooking loss $(\mathrm{CL}, \%)$ was determined in the left $m$. biceps femoris. The meat samples were individually placed inside polyethylene bags in a water bath at $75^{\circ} \mathrm{C}$. The samples were heated to $70^{\circ} \mathrm{C}$ (monitored with thermocouples placed in the core) and cooled for $30 \mathrm{~min}$ under running tap water. The samples were then dried with filter paper and weighed. The $\mathrm{CL}$ was expressed as the percentage of weight loss relative to the initial weight, according to the methods published by Silva et al. 1999. After measuring the $\mathrm{CL}$, the samples were stored overnight in a refrigerator $\left(4^{\circ} \mathrm{C}\right)$. The tenderness of the samples was determined by measuring the Warner-Bratzler Shear Force $\left(\mathrm{WBSF}, \mathrm{kg} \cdot \mathrm{cm}^{-2}\right)$ after reaching room temperature. The WBSF was measured in sub-samples that were $1 \mathrm{~cm}^{2}$ in cross section and $2.5 \mathrm{~cm}$ in length. The fibres were placed perpendicularly to the direction of the blade, driving at $100 \mathrm{~mm} \cdot \mathrm{min}^{-1}$, which was attached to a Stevens QTS 25 Texture Analyser (Stevens Advanced Weighing Systems Ltd., Great Dunmow, England). The myoglobin pigment concentration of the $m$. biceps femoris was measured according to the method proposed by Trout 1991, which is particularly suitable for meat with low pigment concentrations. 


\section{Statistical analysis}

Data were analysed using analysis of valiance (ANOVA) procedures for continuous variables with the housing treatments as the factor. The means were compared using Tukey's test. Statistical significance was accepted at $P<0.05$, and the analyses were performed using JMP 5.0.1 (SAS Institute Inc., Cary, NC, USA).

\section{Results and discussion}

Some limitations of the research unity reduced the capability to have large open air parks with available forages, allowing a higher number of rabbits. This fact determined an initial number of rabbits per treatment lower than what is commonly used in other assays, and might have influenced the significance of results obtained. Although, the results showed a general trend of housing system effects on growth performances, carcass characteristics and meat quality.

\section{Growth performances}

The sex of the rabbits did not influence the growth performance parameters, carcass characteristics and meat quality, confirming the observations of Oliveira \& Lui (2006), who studied rabbits of a similar age. In the growing period, the mortality was not controlled. During the fattening period, two rabbits died that were housed in cages, and one died in the open-air pens. However, mortality was not statistically analysed due to the low number of deaths in the study.

The results of the growth trial are summarized in Table 1 and Figure 1. In the growing period, the two groups of rabbits were lodged in the same type of housing system and exposed to the same conditions, so there were no differences in live weight, feed intake, and daily weight gain between the two groups. The growth performance values were in agreement with those observed in previous trials conducted under similar conditions (Pinheiro et al. 2009).

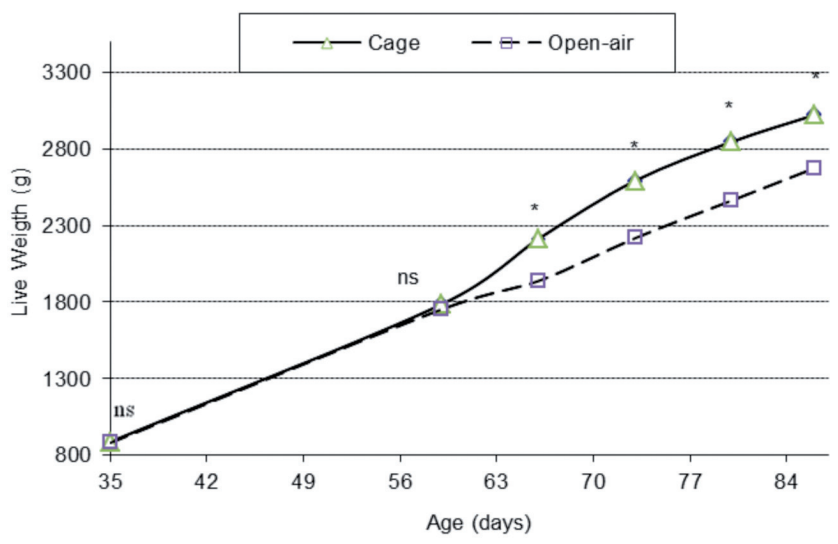

ns: not significant, ${ }^{*} P<0.0001$

Figure 1

Effects of housing systems on the live weights of rabbits during the fattening period 
Table 1

Effects of housing systems on rabbit growth performance

\begin{tabular}{|c|c|c|c|}
\hline & \multicolumn{2}{|c|}{ Housing system } & \multirow[t]{2}{*}{ SEM } \\
\hline & Open-air ${ }^{1}$ & Cages $^{1}$ & \\
\hline \multicolumn{4}{|c|}{ Live weight, g } \\
\hline at $35 d^{2}$ & 888 & 880 & 8.3 \\
\hline at $59 \mathrm{~d}$ & 1752 & 1785 & 14.5 \\
\hline at $87 \mathrm{~d}$ & $2705^{b}$ & $3062^{\mathrm{a}}$ & 48.7 \\
\hline \multicolumn{4}{|c|}{ Weight gain, $g \cdot d^{-1}$} \\
\hline $35-59 d^{2}$ & 36.0 & 37.7 & 1.2 \\
\hline $59-66 d$ & $26.4^{b}$ & $61.2^{\mathrm{a}}$ & 1.9 \\
\hline $66-73 d$ & $39.9^{b}$ & $54.2^{\mathrm{a}}$ & 1.1 \\
\hline $73-80 d$ & 35.0 & 36.2 & 1.2 \\
\hline $80-87 d$ & 35.3 & 29.6 & 1.5 \\
\hline $59-87 d$ & $34.2^{\mathrm{b}}$ & $45.9^{\mathrm{a}}$ & 0.8 \\
\hline \multicolumn{4}{|c|}{ Pellet feed intake, $\mathrm{g} \cdot \mathrm{d}^{-1}$} \\
\hline $35-59 d^{2}$ & 121 & 124 & 3.7 \\
\hline $59-87 d^{3}$ & 110 & 163 & 4 \\
\hline
\end{tabular}

${ }^{1} n=48$ per treatment for live weight and weight gain, $n=12$ per treatment for feed intake for $35-59 d$, and $n=1$ per treatment for feed intake in open-air park ${ }^{2}$ During days $35-59$, all the rabbits were lodged in cages. ${ }^{3}$ Statistical analysis was not done due to sample size in the open-air $(n=1)$. abValues with different letter in same line are significantly different $(\mathrm{P}<0.05)$.

In the fattening period ( 59 to $87 \mathrm{~d}$ ), the rabbits reared in cages had a significantly higher final live weight ( $357 \mathrm{~g}$ or $13 \%$ greater) than the open-air rabbits. In this period, the weight gain was also significantly higher in rabbits reared in cages, which is in accordance with the results observed by Lambertini et al. (2001) McNitt et al. (2003). The weight gain and feed intake of the caged rabbits were $34 \%$ and $48 \%$ higher than the rabbits in the open-air system, respectively. Probably, the intake of pasture in the open-air group, not determined in this essay, did not fully compensate for the reduction of pellet feed intake. Consequently, the nutrient intake and the weight gain were reduced (McNitt et al. 2003). Also Jekkel et al. (2010) found a decrease in the growth of rabbits housed in conventional systems, when compared with housing in different types of parks, but do not have observed effects in feed intake and conversion ratio. The reduction in feed intake in the outdoor rearing systems has been reported to play a role in lowering weight gains (Mertens \& van Oeckel 2000). However, other factors associated with open-air pens also contribute to the negative effects observed on growth performance. In fact, open-air pens increase the energy maintenance requirements of rabbits, since they provide more space for animal movement, which increase locomotors activity (Mertens \& van Oeckel 2000) and thermoregulation expenditures (Verga 2000). The available space had a negative effect on growth performance in a study where the size of a park was even lower than that of the pen used in the present study, as observed by Princz et al. (2008). The increased energy requirements combined with the decrease in feed intake might result in lower growth.

The treatments had no effects on the weight gains and live weights of the rabbits during the growing period when the housing systems were similar (Figure 1). However, when the open-air group was moved to the pasture pen, these rabbits experienced a significant decrease in weight gain ( 26.4 vs. $61.2 ; P<0.05)$. As time passed, the negative effects of the 
open-air treatment on growth were less evident, and after 73 days the weight gain was similar to that observed in the caged rabbits (Table 1). This change in weight gain could indicate that the animals experience adaptation problems in the new housing system, which contributes to the decreased growth performance.

\section{Carcass characteristics}

The effects of housing treatments on the carcass characteristics at $87 \mathrm{~d}$ are presented in Table 2. The caged rabbits had higher slaughter weights, reflecting their greater weight gain, as discussed previously, and higher hot and chilled carcass weights in comparison to the open-air group. The dressing out percentage in the caged rabbits was similar to that of the open-air rabbits, which confirms the findings of Mertens \& van Oeckel (2001) and Dalle Zotte et al. (2008). However, Dal Bosco et al. (2000) and Metzger et al. (2003) observed that there were negative effects of the pens on the dressing out percentage. The lack of statistical significance in present study findings is probably due to the low number of rabbits studied.

Table 2

Effects of housing systems on rabbit carcass characteristics

\begin{tabular}{lccc}
\hline & \multicolumn{2}{c}{ Housing system } & SEM \\
& Open-air & & \\
\hline Slaughter live weight, g & $2717^{\mathrm{b}}$ & $3091^{\mathrm{a}}$ & 47.5 \\
Hot carcass, g & $1647^{\mathrm{b}}$ & $1901^{\mathrm{a}}$ & 33.6 \\
Chilled carcass, g & $1627^{\mathrm{b}}$ & $1879^{\mathrm{a}}$ & 33.4 \\
Dressing out percentage (DP) & 59.9 & 60.7 & 0.32 \\
Drip Loss Percentage (DLP) & 1.20 & 1.15 & 0.09 \\
Reference carcass & & & \\
$\quad$ weight, g & $1333^{\mathrm{b}}$ & $1490^{\mathrm{a}}$ & 23 \\
percentage of chilled carcass & $81.96^{\mathrm{a}}$ & $79.33^{\mathrm{b}}$ & 0.33 \\
Head, \% chilled carcass & 7.31 & 6.63 & 0.11 \\
Liver, \% chilled carcass & 6.26 & 6.74 & 0.16 \\
Kidneys, \% chilled carcass & 1.12 & 1.11 & 0.03 \\
Heart and lungs, \% chilled carcass & 1.87 & 1.94 & 0.05 \\
Dissectible fat, \% reference carcass & $1.66^{\mathrm{b}}$ & $5.29^{\mathrm{a}}$ & 0.41 \\
Hind part, \% reference carcass & $34.94^{\mathrm{a}}$ & $33.10^{\mathrm{b}}$ & 0.24 \\
\hline
\end{tabular}

${ }^{1} \mathrm{n}=12$ per treatment, abValues with different letter in same line are significantly different $(P<0.05)$.

In the present trial, the open-air rabbits had a higher reference carcass percentage, which is probably due to the decreased viscera weight, although this difference was not significant. The observed viscera weight in this study was greater than the weight previously reported by Pascual \& Pla (2007), which is likely because these researchers studied younger and lighter rabbits, and age is known to affect the development of specific tissues and organs (Ouhayoun 1998).

The dissectible fat content in the carcasses of the rabbits in the open-air treatment was significantly lower (only 1/3) than that observed in the caged rabbits. Additionally, Dal Bosco et al. (2000) observed a lower lipid content in the carcasses of rabbits reared in open-air or indoor pens than in caged rabbits. Reductions in the energy available for growth and fat deposition likely contributed to this effect. 
The open-air group had a higher proportion of the hind part (34.9 vs. 33.1; Table 2), less meat on the hind leg, a higher bone proportion, lower meat/bone ratio, and the femur had a larger diameter (Table 3). These effects are related to the increased exercise permitted in the openair system, which has a larger available space. The results of this study are in accordance with those of Dal Bosco et al. (2000). In contrast, Metzger et al. (2003) did not observe any effects on muscles or the meat: bone ratios in the hind part when rabbits were lodged in a similar density in pens or cages.

Table 3

Effects of housing systems on rabbit hind leg characteristics

\begin{tabular}{lccc}
\hline & \multicolumn{2}{c}{ Housing system } & SEM \\
& Open-air ${ }^{1}$ & Cages $^{1}$ & \\
\hline Hind Leg & & & \\
meat,\% hind leg & $79.34^{\mathrm{b}}$ & $81.94^{\mathrm{a}}$ & 0.54 \\
bone,\% hind leg & $19.07^{\mathrm{a}}$ & $16.64^{\mathrm{b}}$ & 0.45 \\
meat/bone & $4.20^{\mathrm{b}}$ & $5.01^{\mathrm{a}}$ & 0.14 \\
Femur & & & \\
$\quad$ weight, g & 14.48 & 14.52 & 0.26 \\
length, mm & 86.11 & 86.58 & 0.88 \\
diameter, mm & $7.23^{\mathrm{a}}$ & $7.02^{\mathrm{b}}$ & 0.05 \\
\hline
\end{tabular}

${ }^{1} n=12$ per treatment, abValues with different letter in same line are significantly different $(P<0.05)$.

\section{Meat quality}

The effects of the housing systems on the meat quality measured in the $m$. biceps femoris are shown in Table 4. The treatments had no effect on the meat pHu at slaughter or the $\mathrm{pHu}_{24 \mathrm{~h}}$ in accordance with other authors (Pla et al. 1996, Pascual \& Pla 2007 and Dalle Zotte et al. 2008). However, the results of this work differ from those of Metzger et al. (2003) since these researchers observed an increase in the meat $\mathrm{pHu}$ of rabbits reared in pens. This difference may be due to the differences in the sizes of the parks and the larger difference between the slaughter weights of the caged and open-air rabbits in the present study.

The carcasses of the open-air rabbits had a significantly lower lightness colour $\left(L^{*}\right)$ and the meat had a higher $(P<0.05)$ redness colour ( $a^{*} ; 31$ vs. -1.65$)$, $C L$ (3.64 vs. $\left.3.02 \%\right)$, WBSF $\left(4.26 \mathrm{vs} .3 .29 \mathrm{~kg} \cdot \mathrm{cm}^{-2}\right)$, and amount of myoglobin pigment (0.41 vs. 0.32 ) than those kept in cages. The increase in the redness of the open-air rabbit meat can be explained by the fact that exercise increases the oxidative capacity of the muscle, which increases the proportion of oxidative myofibres (transition of type IIB to type IA fibres) and the myoglobin content (Monin \& Ouali 1991). Dalle Zotte et al. (2003) and Pla (2008) also observed increases in meat redness, although their conditions differed from this study as previously mentioned.

The $\mathrm{CL}$ values observed were lower than those reported in other works (Pascual \& Pla 2007), which is probably a result of the methodology used, namely the lower cooking time and temperature used. The $\mathrm{CL}$ was higher in the open-air rabbits (about $20 \%$ more) than in the caged rabbits, which is probably due to the lower fat content and different maturity degree of the meat because of the lower growth rate (Lukefahr et al. 1983). The open-air treatment increased the WBSF. This results was in accordance with Pla (2008) but not with of Combes et al. (2003) and Metzger et al. (2003) who observed no effects of organic production 
on the WBSF of rabbit meat. In this study, the higher WBSF of open-air rabbit meat may be related with the higher cooking loss.

Table 4

Effects of housing systems on carcass meat quality (m. biceps femoris)

\begin{tabular}{|c|c|c|c|}
\hline & \multicolumn{2}{|c|}{ Housing system } & \multirow[t]{2}{*}{ SEM } \\
\hline & Open-air ${ }^{1}$ & Cages $^{1}$ & \\
\hline \multicolumn{4}{|l|}{$\mathrm{pHu}$} \\
\hline slaughter & 6.96 & 7.04 & 0.05 \\
\hline $24 \mathrm{~h}$ post-mortem & 5.96 & 6.01 & 0.04 \\
\hline$\Delta$ & 1.08 & 0.95 & 0.07 \\
\hline \multicolumn{4}{|l|}{ Carcass colour } \\
\hline lightness, $\mathrm{L}^{*}$ & $50.72^{b}$ & $53.12^{\mathrm{a}}$ & 0.50 \\
\hline redness, a* & 3.73 & 3.66 & 0.42 \\
\hline yellowness, $b^{*}$ & 5.22 & 4.98 & 0.46 \\
\hline \multicolumn{4}{|l|}{ Colour of $m$. biceps femoris } \\
\hline lightness, $L^{*}$ & 53.99 & 56.50 & 0.70 \\
\hline redness, $\mathrm{a}^{*}$ & $-0.31^{\mathrm{a}}$ & $-1.65^{\mathrm{b}}$ & 0.22 \\
\hline yellowness, b* & 3.28 & 2.67 & 0.26 \\
\hline Cooking loss, $\%$ & $3.64^{\mathrm{a}}$ & $3.02^{\mathrm{b}}$ & 1.52 \\
\hline WBSF, $\mathrm{kg} \cdot \mathrm{cm}^{-2}$ & $4.26^{\mathrm{a}}$ & $3.29^{\mathrm{b}}$ & 0.22 \\
\hline Myoglobin pigment, $\mathrm{mg} \cdot \mathrm{g}^{-1}$ & $0.41^{\mathrm{a}}$ & $0.32^{\mathrm{b}}$ & 0.02 \\
\hline
\end{tabular}

${ }^{1} \mathrm{n}=12$ per treatment, abValues with different letter in same line are significantly different $(P<0.05)$.

Open-air rabbits had a meat with higher content of myoglobin and redness $\mathrm{a}^{*}$ than those kept in cages. The relationship between the meat redness and the myoglobin concentration of the rabbit biceps femuris muscle is presented in Figure 2. The correlation was acceptable $(r=0.64)$ and showed that increases in the myoglobin content were correlated with increases in the CIELAB a* values (increased meat redness). To date, there have been no studies on whether consumer decisions to eat rabbit meat are influenced by rabbit meat colour.

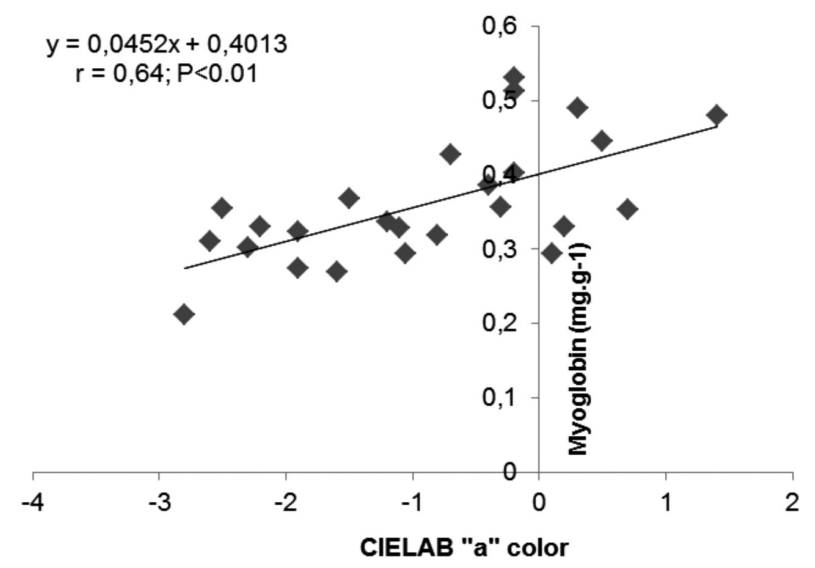

Figure 2

Relationship between meat colour (CIELAB redness, $\mathrm{a}^{*}$ ) and myoglobin concentration in biceps meat of rabbits housed in cages or the open-air system $(n=24)$. 


\section{References}

Blasco A, Ouhayoun J (1996) Harmonization of criteria and terminology in rabbit meat research. Revised proposal. World Rabbit Sci 4, 93-99

Cavani C, Bianchi M, Lazzaroni C, Luzi F, Minelli G, Petracci M (2000) Influence of type of rearing, slaughter age and sex on fattening rabbit: II. Meat quality. In: Proc 7th World Rabbit Congr, 4-7 July, Valencia, Spain, 567-572

Combes S, Lebas F, Juin H, Lebreton L, Martin T, Jehl N, Cauquil L, Darche B, Corboeuf MA (2003) Comparison of standard rabbit and Bio rabbit: Sensory analysis and mechanical tenderness of the meat. In: Proc 10èmes Journ Rech Cunicole, 19-20 November 2003, Paris, France 137-140

Dal Bosco A, Castellini C, Bernardini M (2000) Productive performance and carcass meat characteristics of cage- or pen-raised rabbits. In: Proc 7th World Rabbit Congr, 4-7 July 2000, Valencia, Spain, 579-583

Dalle Zotte A, Princz Z, Metzger SZ, Radnai I, Biró-Németh E, Orova Z, Szendrő ZS (2008) Response of fattening rabbits reared under different housing conditions. 2 Carcass and meat quality. Livest Sci 122, 39-47

Jekkel G, Gábor MilisitsG, Nagy I (2010) Effect of alternative rearing methods on the behaviour and on the growth and slaughter traits of growing rabbits. Arch Tierz 53, 205-215

Lambertini L, Vignola G, Zaghini G (2001) Alternative pen housing system for fattening rabbits: effects of group density and bitter. World Rabbit Sci 9, 141-147

Lebas F (2001) Fattening farms: advantages and disadvantages. Cuniculture 28, 163-168 [in French]

Lukefahr S, Hohenboken WD, Cheeke PR, Patton NM (1983) Appraisal of nine genetic groups of rabbits for carcass and lean yield traits. J Anim Sci 57, 899-907

Maertens L, van Herck A (2000) Performance of weaned rabbits raised in pens or in classical cages: first results. World Rabbit Sci 8 (Suppl 1), 435-440

Maertens L, van Oeckel MJ (2001) Effect of housing rabbits in cages or in parks and its enrichment on performances and meat colour. In: Proc 9ème Journ Rech Cunicole, 28-29 November, Paris, France, 31-34

Marai FM, Rashwan AA (2003) Rabbits behaviour under modern commercial production conditions - a review. Arch Tierz 46, 357-376

Marai IFM, Rashwan AA (2004) Rabbits behavioural response to climatic and managerial conditions - a review. Arch Tierz 47, 469-482

McNitt J, Way R, Way M, Forrester-Anderson I (2003) Growth of fryers reared and (or) finished using controlled grazing in movable pens. World Rabbit Sci 11, 189-198

Metzger SZ, Kustos K, Szendrõ ZS, Szabó A, Eiben CS, Nagy I (2003) The effect of housing system on carcass traits and meat quality of rabbit. World Rabbit Sci 11, 1-11

Monin G, Ouali A (1991) Muscle differentiation and meat quality. In: Lawrie R (ed.) Developments in meat science. Elsevier Applied Science, London, UK/New York, USA, 89-157

Morisse JP, Boilletot E, Martrenchar A (1999) Wire or litter floor, affect the rabbit choice and well-fair. In: Proc 8èmes Journ Rech Cunicole, Paris, France, 63-66

Oliveira MC, Lui JF (2006) Growth performances, carcass characteristics and economic viability of sexed rabbits slaughtered at different ages. Arq Bras Med Vet Zoot 58, 1149-1155 [in Portuguese]

Ouhayoun J (1998) Influence of the diet on rabbit meat quality. In: De Blas C, Wiseman J (eds.) The nutrition of the rabbit. CABI Publishing, Wallingford, UK, 177-195

Ouhayoun J, Dalle Zotte A (1996) Harmonization of muscle and meat criteria in rabbit meat research. World Rabbit Sci 4, 211-218

Pascual M, Pla M (2007) Changes in carcass composition and meat quality when selecting rabbits for growth rate. Meat Sci 77, 474-481

Pinheiro V, Guedes CM, Outor-Monteiro, D, Mourão JL (2009) Effects of fibre level and dietary mannanoligosaccharides on digestibility, caecal volatile acids and performances of growing rabbits. Anim Feed Sci Technol 148, 288-300 
Pinheiro V, Mourão JL (2007) Alternative production systems for fattening rabbits. In: Proc Congr Ibérico de Cunicultura da APEZ e ASESCU, June 2007, Vila Real, Portugal, 163-173

Pla M (2008) A comparison of the carcass traits and meat quality of conventionally and organically produced rabbits. Livest Sci 115, 1-12

Pla M, Fernández P, Blasco (1996) A Carcass composition and meat characteristics of two rabbit breeds of different degrees of maturity. Meat Sci 44, 85-92

Princz Z, Dalle Zotte A, Metzger S Z, Radnai I, Biró-Németh E, Orova Z, Szendrő ZS (2008) Response of fattening rabbits reared under different housing conditions. 1. Live performance and health status. Livest Sci 121, 86-91

Rodrigues MAM, Guedes CM, Cone JW, van Gelder AH, Ferreira LMM, Sequeira CA (2007) Effects of phenolic acid structures on meadow hay digestibility. Anim Feed Sci Tech 136, 297-311

Trout GRA (1991) A rapid method for measuring pigment concentration in porcine and other low pigmented muscles. In: Proc 37th ICMST, 1-6th September 1991, Kulmbach, Germany, 1198-1201

Verga, M (2000) Intensive rabbit breeding and welfare: development of research, trends and applications. World Rabbit Sci 8 (Suppl 1), 491-509

Received 27 January 2011, accepted 20 September 2011.

Corresponding author:

Victor Pinheiro

email: vpinheir@utad.pt

Departement of Animal Science, Universidade de Trás-os-Montes e Alto Douro (UTAD), Apart. 1013, 5001-801 Vila Real, Portugal 